\title{
Academic course: ABOUT AND AROUND CURATING: THE TECHNOLOGY OF AN EXHIBITION PROCESS-The Realization of project "Real World"
}

As an extended part of independent curatorial project About and Around Curating / Kustosiranje, art historians and freelance curators Bereta and Tunić developed a special academic course for the University of Belgrade, Faculties of Architecture and Fine Arts during the autumn semester 2012/13. Rooted in experience based methodology and inspired by contemporary curatorial studies in Europe, the official course curriculum gathered undergraduate students of Architecture, Fine Arts (Department of Sculpture) and Art Historians. The aim of the course was to encourage team working of students of different backgrounds in order to create newly produced artworks, as part of a group exhibition. The course itself was intended to be a reaction and constructive critique towards the lack of cooperation between art faculties, low rate of practical activities during studies and seeing curatorial studies solely as a world of ideas. 
This paper explores the possibilities in education about curatorial practice, through analysis of one academic course which took place at the University of Belgrade for students of Architecture, Fine Arts Academy (Department for Sculpture) and future Art historians during the autumn semester of 2012. The course was developed at call in and cooperation with professors Milorad Mladenović (Faculty of Architecture) and Radoš Antonijević (Faculty of Fine Arts). The approach was empirical and different from the most dominant methods in the Serbian school system. Through this course the intention was to address three specific issues:

The lack of any practical course for undergraduate students regarding art curating and production.

Cooperation between faculties, in order to offer their students a kind of crossover knowledge and experience through mutual courses about issues which are in close relation with professional challenges which they will come across after graduation. Instead of a dry critique, as a possible solution, one course for the students of different faculties was created, in order to give them an opportunity to experience challenges in the "real world".

Speaking in a simplified fashion, curatorial practice is widely (stereotypically) perceived as an activity which demonstrates possible realization of an idea, through conceptualization and, usually through the language of artworks in an exhibition (considered as a medium). Not quite opposite from that standpoint, but with more sense for disseminating and recognizing the processes stages, it is believed that art curating is a technological process, which includes more activities, than usually mentioned. Moreover, different activities are countlessly correlated and in constant interaction between each other. If an exhibition is something that could be understood as a final visible result ${ }^{1}$, it is believed that same process might be understood as a complex set of activities including, for example business planning, and a whole set of different skills in order to reach the same goal. Those activities are usually parallel, and dependable on each other. Specific multitasking is something that almost inevitably art curator is defined nowadays as precarious cultural worker, with potent entrepreneur skills ${ }^{2}$.

Also, the aim of this course was to open possibilities for future artists, art historians and architects for producing a new artwork. That new artwork would be the result of their mutual work, the proof and mirror of their knowledge 
gained. That result is not necessary something what one might understand as a new contemporary art production, but definitely more than an ordinary scholar practice.

\section{ORGANIZING COURSE, DIFFERENT BACKGROUNDS}

Challenging invitation by two faculties' professors (Architecture and Fine Arts) of the University of Belgrade (UB) to create the curriculum ${ }^{3}$ for their students, resulted in one experimental proposal for one semester course for undergraduate students (Autumn/Winter 2012/2013). ${ }^{4}$ The idea was to add one more group to the course, the students of The Department of History of Art (Faculty of Philosophy). It was believed that mixing different scholars' backgrounds and various approaches could be more efficient and educative for each student. While professors Mladenović and Antonijević recruited students from their faculties, according to the propositions they followed, the students of History of Art were invited by an Open Call to participate. This also opened up an opportunity to change locations for sessions, which was both a new practice for all of us (particularly an organisational challenge) and one more factor for strengthening educational process. Current art events in Belgrade were also part of the curriculum, where we had a chance to learn from each other by evaluating same art events with different and individual approaches. This was one of the ways to open the course towards the ,real” surrounding art world and current production. Seven students were recruited from each faculty, altogether numbering twenty-one.

Overcoming the lack of operative and interactive cooperation between faculties or even departments at the same school at UB in teaching process was more

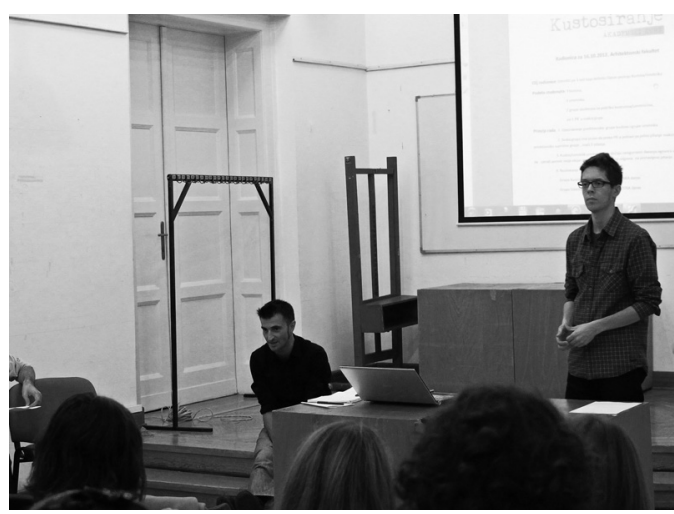

Figure 01 . Photo by Milorad Mladenović

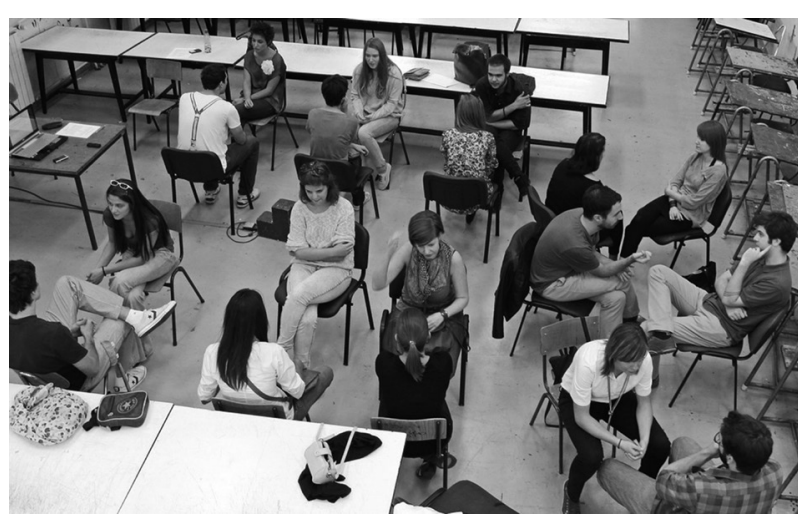

Figure 02 . Photo by Milorad Mladenović 
challenging obstacle than actually expected. ${ }^{5}$ This situation led to some logical presumptions. The students from different faculties were at the beginning very distant towards each other. While the students of Fine Arts were already accustomed to working in small groups and cooperating closely, the future art historians were having their lessons predominantly in classrooms, where they often mixed with different generations of colleagues and usually were not used to work in teams. The future architects were oriented towards working closely in teams and solving their scholar tasks as group projects. The last, but not the least, bridging gaps between theory and practice lies as a core issue for most educational programmes, which was intensified by having undergraduate students from three (still, art) faculties. Idealistically, it was expected from our students to possess certain knowledge about art and curatorship in order to develop a structuralized approach with practical solutions and skills with clear intentions for producing a new artwork, as one of the course's result.

\section{METHODOLOGY, APPROACH}

The methodology used for building this course, as well as for the previous and later programs 6 , might be described as experience-based ${ }^{7}$. Different, or even opposite to didactical, which is the dominant method in Serbian educational system on every level, our approach was oriented towards acquiring the experience of all stakeholders, including us, the teachers. Understanding learning process as expanding personal experiences spanning over one's whole lifetime, gained individually or in interaction with others, it was tried to gradually take issues as challenges, to reach mutual goal. Believing that every person has many skills, and even if he/she is sometimes unaware of them as skills, we tried to provoke situations, which could bring them to surface.

The lessons taught to the students were taken as a set of possible solutions, different viewpoints of the same matter, trying to underline the possibility of creative interpretation of each student by the given concept. For instance, when Art Curator was the topic, we tried to explain the activities which the profession might consist of, depending on circumstances, work environment and responsibilities, which could be further developed by one's individual choices and affinities.

During the first encounter with the students, after having presented the topics of forthcoming Academic course and phases/steps of realization, several words or terms, important as a structure for the concept of the course, were underlined. 
- Proactivity was explained as a (preferred) choice of strategy. The aim was to open a possibility for students' self-reflection and future selfeducation, avoiding decision making which is "reserved" for authorities in charge of the course (us and professors).

- Share culture was understood as a necessary condition for equivalency, the balance between what we give (as teachers), in exchange for what we take from the others (the students). This point was seen as very important for gaining new information, knowledge and for building healthy interpersonal relations.

- Openness as a preferred personal attitude. It was believed that behind every quality result there lied successful collaboration between the individuals who share different roles and responsibilities between each other, as a team work.

- Argumentation was considered as a necessity both as a background for an opinion, personal statement, as well as a solid material for group in building mutual structure, in order to achieve a goal.

- This list of responsible terms included one more word - transparency, which was understood both as an educational and ethical choice, because it made all stages of the process visible for all participants in the course.

The first meeting included one short role-play, in order to gain each other's' attention, and to understand the importance of communication between colleagues, no matter how individual differences and not being familiar with the most of the group might be an obstacle. Following this short game, the atmosphere become more relaxed, and we were sure that our methodology started reaching our participants. By avoiding pre-made definitions and

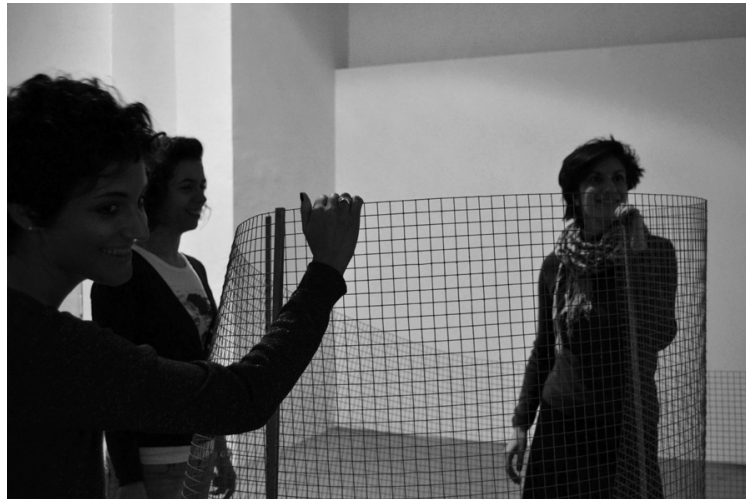

Figure 03. Photo by Anastasja Protić

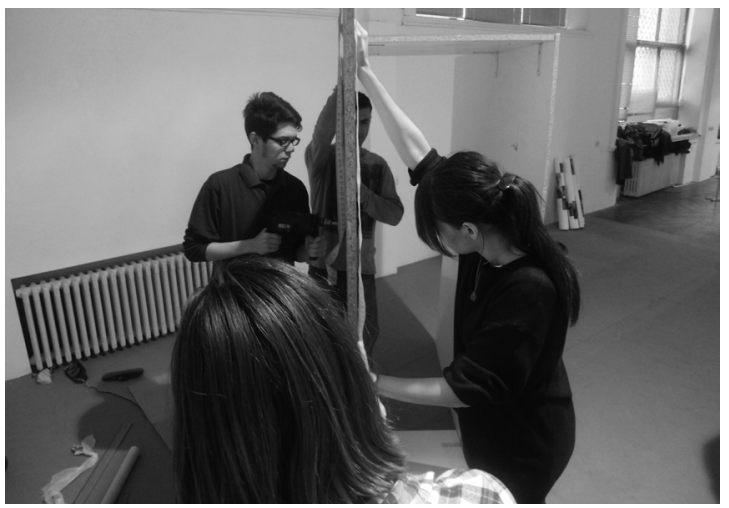

Figure 04 . Photo by Nina Ivanović 
predominant theory approach, the aim was to focus on students' ideas and experience-based learning. Every meeting or session, as our official encounters were called, also included feedback from students, as a small evaluation test, sent via e-mail.

\section{TOPICS AND STAGES OF WORK}

The intention was to cover topics which could be useful for the final result of this course and to gain knowledge and skills necessary for maintaining an artistic project. It has already been mentioned that curating is not only about creating a concept, based entirely on certain aesthetically researched profound idea, which seeks ultimate realization. It is a way more complex activity, which seeks for multitasking, shifting between different methodologies, in order to achieve an artistic aim ${ }^{8}$. This demanding position engages different sets of skills of each individual and some of them are not even close to artistic practice, as usually known. ${ }^{9}$ As mentioned earlier, approaching the same task from different angles is an important strategy for a successful result. The choice of topics for this course was made based on our professional experience, examples of other professionals ("good practice") and beliefs that these were relevant for students' forthcoming production and independent work.

Curriculum was divided into three stages. While the first part was dedicated to introduction and team working, the second one was creating an exhibition project and the final stage was a group exhibition. Each stage had its outcome in a scholar manner. After the first part, followed by the colloquium, at the end of the second part the students acquired the certificate of their attendance and participation throughout the course, followed by ECTS points. The exhibition was presented as an exam.

Most of the topics were dedicated to the production process. ${ }^{10}$ While a part of the topics was covered by creating a concept generated from ideas, the other topics were focused on project activities - seeing exhibition as a project. Overall, the intention was to explain key relations in art curating.

Context was explored by paying attention to different angles and the way of comprehending an artwork in its original habitat - social, historical, technical, aesthetic, among others, merits. Who defines who; how do we understand a statement of an artist through his/ hers work, and how many levels of interaction need to be considered while creating and exhibiting. One Carravaggio's and Damian Hirst's artwork each were shown as examples. 
Perception of an artwork presented a few possibilities of different ways or techniques for analysing. Production and post-production of an artwork was dedicated to a less known part of creating for the students. Surprisingly, this topic was not very common for Fine arts' students either. It raised questions closely correlated between profound issues of aesthetics and materializing an idea, even if it was tried to approach the topic on a more technical matter. Developing a concept meant to focus on complex structure generically evolved from sketches of ideas to the final form. Personal artistic statements included short presentations of three Serbian artists and one art curator from Croatia. The artists explained one of their phases underlining some key artworks in their on-going profession, explaining steps from very early ideas until finalization. The curator discussed his standpoint, using his own former exhibition projects, to pinpoint aims and openly talked about obstacles in work he had. ${ }^{11}$ On curating two different meetings were dedicated - (Art) Curator, how to define a profession and Curator and artist, a role-play, explained in the previous chapter.

As mentioned, it was insisted on importance of involving project planning activities as parallel and interactive process together with the one which gradually evolved from idea to the concept. ${ }^{12}$ That was the main reason for creating other set of topics, which generally covered business activities of a cultural entrepreneur, at small scale. Workshops included simulation of applying for a grant, fundraising, timeline of activities, developing a budget, outcomes as visible effects and exhibition as a project. It was clear from the beginning that curatorial practice was neither a business activity, or exclusively an evolving journey in the world of ideas.

The course included one more important stage - production. This means that small teams of (at least) three students, each from different Faculty, were formed in order to create their artwork, as a team. First colloquium was obligatory for all students of all three faculties and consisted of $7+3$ minutes of presentation $-M y$ (ideal) exhibition. Two important results were achieved: each student presented the aims and ideas and discussed about them with the others in maximum threeminutes' long debate in order to articulate possibilities for matching with other future members of the group; presentations were short, accurate and followed by some visual background using slideshow. Facebook page, opened for internal course discussions was used in order to gain the best possible matching and form new groups based on students' choice, as well as professors' suggestions. A special blog was opened too, which followed the main activities of the course, serving as an important online base for visitors and press. ${ }^{13}$ 
Production, as the main goal, which would lead to the final stage - exhibition, was very complex and most innovative stage to follow, for us as authors. This process included many different activities for students, such as - multitasking, questions of creativity (what it is, actually?), using various skills, teamwork, meeting the deadlines, collaborating with differences in approaches, choosing most appropriate medium, among others. From some point, when the students assumed full responsibility and functionality of their teams, we suggested to use the opportunity to "switch" their roles and test each other's point of views in order to reach the mutual goal - creating a new artwork, based on one concept, in which all of them believed. Quite intentionally, they were faced with some logical and common obstacles. Budget of every team, for instance, was something that required different activities, mostly oriented towards additional research. When an invitation from Art space U10 in Belgrade ${ }^{14}$ was officially received and acclamation that we are included in their official program for exhibitions in 2013, this ignited another set of inquiries by the students - the dimensions of gallery space, positioning of artworks and technical requirements. At our meetings, when all groups shared their concept proposals among each other, another question was opened - what is the main line, or key words of our group exhibition? We actually started to build an overall concept with them, in a generic way, based on proposed ideas. The intention was oriented towards the awareness of each member of all teams of their group exhibition. Dense concept of future exhibition was out of question, but some key points were the most we could expect in gaining that goal.

Preparation and physical installation of each teams' artwork was a new experience for most of the students. We insisted that outsourcing most of technical assistance was not something we can afford. From the beginning

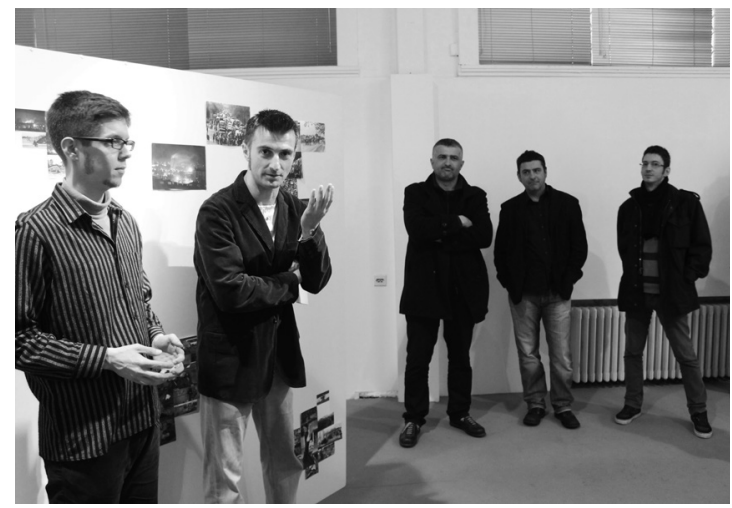

Figure 05. Photo by Kristina Grebenar

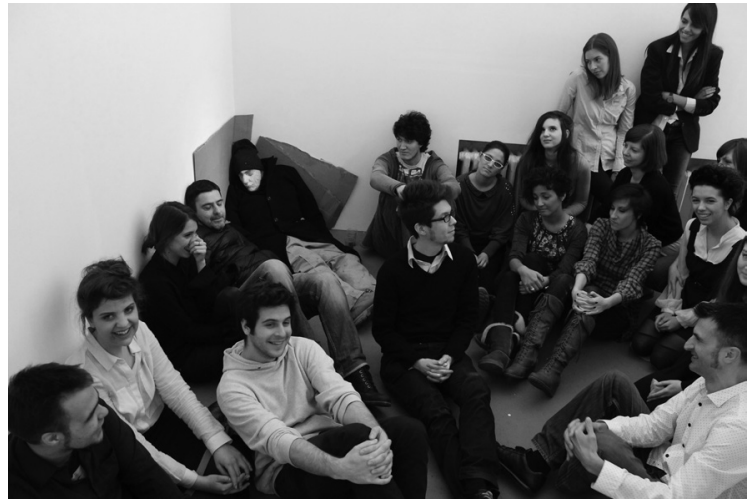

Figure 06. Photo by Nina Ivanović 
they were aware that besides creating their work, from ideas, through conceptualization, production until installation - they were on their own, with our assistance. Also, another prerequisite was to create a short text, which would describe each artwork to the public. It was a typical task for curator regarding catalogue. It was not insisted that any activity should come from expected background of any of the students; it was proposed that they collaborated among each other and find for themselves most appropriate position, a role in the team.

\section{EVALUATION AND CERTIFICATE}

Three different evaluations over the entire process were included, which were considered vital both for us, as course's organisers, and for the students' way of expressing personal and critical attitude.

After our very first encounter the students received the evaluation with an open space with one question to fill in: My expectations of this course? And the keywords in relation to those expectations. This input was found as valuable data not to fill out their wishes, but to keep visible the students' interest on our agenda for this course and also test our own plan of activities.

The main reason for the evaluations during the process was to find out about students' pulse of attention, their interest for topics and their opinion about organizational matters of the course in order to improve the approach that flow of information could reach without any major interruption. As mentioned, the evaluation chart was e-mailed to each student individually the same day, after each meeting. The first part was a questionnaire and consisted of the following questions: 1) Chosen topic I find interesting, 2) The topic is explained..., 3) Approach to topic, 4) Time and place for this session. The grades they choose ranged in the scale from 5 to 10 , same as grading system at the Serbian faculties. Grade 5 is negative, and 10 is the highest one. The second part was not obligatory and it was open for their comments, reactions and advices regarding that particular session or the whole course.

Evaluation chart for exhibitions was our originally developed chart model in order to create a starting point for critical and argumentative debate about an exhibition that one group of participants visited together at a certain art space with public guidance by curator of the same event. Before this Academic course it had been developed and used for over a year, on different public occasions in About and around curating / Kustosiranje project. Without any intention to 
measure immeasurable values, it was developed for one and only reason - to open space for critics, arguments and with respect to anyone's opinion. ${ }^{15}$

Every student, from each faculty received Certificate of attendance on Academic course after the final stage - a group exhibition titled About and Around Curating: $7 \times 3$. Future art historians found this document valuable because The Department of History of Art did not participate officially in this course and their students did not receive any ECTS credits.

\section{CRITICAL STANDPOINT}

Critical approach was built to topics through open discussions on each session. For example, as a part of one particular session, held at The $53^{\text {rd }}$ October Salon in Belgrade (Good life) $)^{16}$, after guided tour specially modified for students and led by several curators of the exhibition, the main task was evaluation. At the next meeting, all students were invited to discuss the $53^{\text {rd }}$ October Salon, and discuss each grade, for different categories in Evaluation chart. On the same occasion different students, visiting the same exhibition, graded differently, which opened up a possibility for discussing evaluation parameters and exhibition standards. Prior to that semi-debate, it was explained that every opinion was relevant, no matter how different it might be from the others, and our goal was to have explanations, reasons and arguments for building a critical approach. The surprise was vivid among the students, noticing different aspects and rating them according to themselves. Summarizing all grades in Evaluation chart led us to the conclusion that visiting the exhibition was very productive for the students.

As an appropriate teaching/presenting method for the topic which tackled sensitive relationship between the artist and curator, a role-play model was chosen. Since complexity of that relationship has been extensively researched, and never could be concluded ${ }^{17}$, the focus was on vitality and importance of communication between two actors. The reason why the actors were chosen within the same field (art, culture) was because it could be easily related to students' experience, having in mind that communication between the two was not mostly fostered within studies and naturally because of the focus of the course itself. The role-play started by dividing two groups of students (mixed from all three faculties), and asking them to think about themselves as one idea in a mind (curator's, artist's). All ideas of each actor should blend into one in order to achieve a compromise - peace in my mind and consensus in further discussion. It was explained that every action sought reaction and that was a 
basic level of communication. It was, as well, a step ahead or backwards from a purely strategic point of view.

The game began with the first action - statement of the curator who proposed to artist the participation in a group exhibition. All artist's ideas expressed their opinions and stated through voice of the artist (one of the student) as a definitive answer. In short, after 5 action-reaction turns, the proposal actually failed, because the curator asked constantly for further modifications, forcing artist to reconsider own artwork's integrity, from artist's viewpoint. Eventually, artist, under the pressure of the importance of that exhibition and a rare opportunity to exhibit as "new in the field", accepted modifications. Curator, in the end stated that artwork was not adequate, because artist was not flexible enough and the piece itself, actually, did not fit into the concept of the exhibition.

This whole role-play was based on a veritable experience of one young artist and it was still fresh at that time, merely two months old, where we did not name the true actors of the conflict in question. It was, unintentionally by us, a very good choice, because most of the students (artist's ideas) could imagine themselves in the same position. On the other hand, ideas of the curator, tried to reach reasons for such twist in communication. This play led to discussion, and pin-pointing crucial moments of that conversation. The analysis of the role-play brought about several conclusions regarding this case. Most important was to realize different standpoints between curator and artist, their perspectives as professional calls, importance of communication and, naturally, their good intentions. However, none of the students concluded that curators were evil or artists were being exploited. This, even as it sounds like a naive conclusion, was very important achievement for us, fighting against prejudices, which seem present too often in artistic world. Our intention was motivated by a strong belief that people must find a way to communicate, to actively develop a mutual ground in relating to their professional goal. Thus, referring to the goal or participating in developing a standard, one should have a powerful basis for professional work, avoiding misleading.

\section{THE EXHIBITION}

The exhibition titled About and Around Curating: $7 x 3$ was opened from $21^{\text {st }}$ March till $6^{\text {th }}$ April, having many visitors, professionals from the local art scene, professors from faculties, students and colleagues. Media coverage was decent and more than that having in mind that after all this was a students' exhibition. 
Public guidance and several discussions organized by our students were also a part of their activities. Most of the newly produced artworks presented at the exhibition were closely related to similar issues, that are dominant in contemporary art production in Serbia and in the region ${ }^{18}$. In the two weeks period, while the exhibition took place, the audience was persistent and according to gallery staff it was noted that average number of visitors reached up to 22 per day (on days when public discussions took a place the number was greater), which for Serbian standards in this matter was a respectable number.

\section{RESULTS AND CONCLUSION}

This academic course was organized as inter-disciplinary, as an example of possible inter-faculty cooperation, even inter-sectorial, because of cooperation between an independent art gallery and public sector faculties. Our proposal to faculties was, also an inter-sectorial cooperation, since we were formally representing Civil Association Artikal, which is run as freelance art curators and art historians. Students gained their goal working closely in teams, passing all stages, creating their own artworks and organizing their own group exhibition. The knowledge gained throughout the process was evaluated by them as important and useful and our efforts graded with very high marks. The interest they shown by them before the beginning of the course 16 ensured us that this kind of course was something what was wanted and required. Finally, this course brought new production of artworks, concepts and texts of a catalogue, achieving more than average scholars' task. The students passed their exam. Our new goal ever since has been to try to achieve continuity and further professional development of this kind of programs. (2013), accessed November 15, 2013. available on http://www.oncurating-journal.org/index.php/ issue-16.html\#.Urr05_RDs_Y 
among others), academic program (started by the course in question) and international networking (dominantly the West Balkans and the Baltic region). More on our past programs at: http:// aboutandaroundcurating.blogspot.com/p/about-and-around-curating-public.html

More on the concept in books: Alice Y. Kolb and David A. Kolb, eds., Experimental learning theory: a dynamic, holistic approach to management, learning, education and development (London: Sage publications, 2008) and David A. Kolb, Richard E. Boyatzis and Charalampos Mainemelis, eds., Experimental learning theory: previous research and new directions (New Jersey: Lawrence Erlbaum, 2000).

Beatrice Jaschke, "Curating: a profession in transition," in Talking about exhibitions, ed. Maria Mussakowska (Krakow: Instytut Historii Sztuki UJ, 2012)

This could mostly be applied to curatorial initiatives rooted in freelance, civil and independent spheres, bearing the weight of precariousness in the contemporary neoliberal economy and market, although it affects also the curators from traditional, state institutions. More in: Zoran Erić and Stevan Vuković, eds., "Precarious labour in the field of art," On-Curating 16 (2013), accessed November 15, 2013. available on http://www.oncurating-journal.org/index.php/issue-16. html\#.Urr05_RDs_Y

Interesting examples of contemporary arts processes (setting, organizing, etc) could be seen in: Sonke Gau, Siri Peyer and Dorothee Richter, eds., "The making of...," On-Curating 5(2010), accessed November 15, 2013. available on http://www.oncurating-journal.org/index.php/issue-5. html\#.Urr4H_RDs_Y

The three artists are ass. Professor Milorad Mladenović, architect and visual artist, Ivan Šuletić, architect and visual artist (Faculty of Architecture), senior lecturer/ass. prof Radoš Antonijević, visual artist/sculptor (Faculty of Fine arts), and curator Vladimir Čajkovac, art historian.

Exhibition as a project approach is considered one of the most practical ways of addressing exhibition as a process in times when both artists and curators are in need for applying for funds, which effects both institutionalised and freelance initiatives. Besides that, by this approach our aim, in a way, was to prepare students for future independent projects, a practice not gained at art universities (with the exception of art and culture management).

http://kustosiranjeakademskikurs.blogspot.com (in Serbian)

This space was opened in 2012 as an initiative by a group of young visual artists from Serbia, led by Nemanja Nikolić, visual artist and de facto curator of the gallery. More on the U10 at: www. u10.com

Coincidentally, in that same period, we have been engaged in one collaborative project with our colleagues from Croatia, participants in the project Curatorial platform (Kustoska platforma). Their participants (around 30), visited Belgrade and as one of the activities we organized for them was a public guidance at the same exhibition of The $53^{\text {rd }}$ October Salon we had couple a days earlier with our students. Both groups were of very similar age. Croatian group of participants was approximately two years older. When we processed the data of both groups, we compared the results and discussed about it at our following meeting with students.

Good life: Physical narratives and spatial imaginations contemporary international exhibition, curated by Branislav DImitrijević and Mika Hannula, was set in The former building of the Geodetic Institute in Belgrade. More about the exhibition: http://www.oktobarskisalon.org/53/53rd-octobersalon/?lang=en.

As an example, a study on artist-curator relations and roles:Henry Jackson Newcomb, The roles of the artist \& curator in relation to the exhbiting of art. Available on:http://jessesimmons. wikispaces.com/file/view/The+Roles + of + The + Artist $+\% 26+$ Curator, + In + Relation + To + The + Exh ibiting + of + Art. + .pdf

Andrej Bereta and Srđan Tunić, eds., Kustosiranje: $7 \times 3$ (catalogue text) (Belgrade: Faculty of Architecture, 2013)

Nearly four times more applications we received from future art historians; on Architecture, that process of selecting was different, but interest was more than tripled. 
American association of museums curators committee. A code of ethics for curators (online). 2009

Bereta, Andrej and Srđan Tunić, eds. Kustosiranje: $7 \times 3$ (catalogue text). Belgrade: Faculty of Architecture. 2013

Erić, Zoran and Stevan Vuković. "Precarious labour in the field of art." On-Curating 16 (2013). Accessed November 15, 2013. Available on http://www.oncurating-journal.org/index.php/ issue-16.html\#.Urr7qvRDs_Y

Gau, Sonke, Siri Peyer and Dorothee Richter. "The making of.... "On-Curating 5 (2010). Accessed November 15, 2013. Available on http://www.oncurating-journal.org/index.php/ issue-5.html\#.Urr7_RDs_Y

Graham, Beryl and Sarah Cook. Rethinking curating: art after new media. Cambridge: MIT, 2010.

Greenberg, Reesa, Bruce F. Ferguson and Sandy Nairne, eds. Thinking about exhibitions. London: Routhledge. 2001.

Jaschke, Beatrice. "Curating: a profession in transition." In Talking about exhibitions, edited by Maria Mussakowska. Krakow: Instytut Historii Sztuki UJ., 2012.

Kolb, Alice Y. and David A. Kolb. Experimental learning theory: a dynamic, holistic approach to management, learning, education and development. London: Sage publications, 2008.

Kolb, David A, Richard E. Boyatzis and, Charalampos Mainemelis. Experimental learning theory: previous research and new directions. New Jersey: Lawrence Erlbaum, 2000.

Kustoske prakse (Curatorial practices). 50. October salon in Belgrade (research available online at: http://www.oktobarskisalon.org/50/50-october-salon/?lang=en). 2009

Love, Karen. Curatorial toolkit: a practical guide for curators. Vancouver: Legacies now, 2010.

Meštrov, Ivana and Mihaela Richter. " Fragmenti kustoskog diskursa (Fragments of curatorial discource). “ ̌̌ivot umjetnost - časopis za suvremena likovna zbivanja (World of artmagazine for contemporary visual arts) 85 (2009).

Newcomb, Henry Jackson. The roles of the artist \& curator in relation to the exhbiting of art. 2011, available on: http://jessesimmons.wikispaces.com/file/view/The+Roles + of + The+Artist + $\% 26+$ Curator, + In+Relation + To+The+Exhibiting + of + Art. + .pdf

Šola, Tomislav. Eternity does not live here anymore - a glossary of museum sins. Zagreb: Tomislav Šola, 2012.

Szczerski, Andrzej. "Curating and the importance of an artwork." In Talking about exhibitions, edited by Maria Mussakowska. Krakow: Instytut Historii Sztuki UJ., 2012.

Tadić, Dimitrije. Gallery and exhibiton spaces of contemporary visual art in Serbia. Belgrade: Anonymous said, 2012. 


\section{IZLOŽBENI PROSTOR SEĆANJA:}

\section{Ritamanaliza Spomen-parka Kragujevački oktobar}

\section{Marija Martinović}

Ratna memorijalna arhitektura u Jugoslaviji nakon Drugog svetskog rata čini značajan deo graditeljskog programa. Označavanje događaja (trauma) iz Drugog svetskog rata je važan činilac sećanja i izgradnje savremenog sistema znanja o tom istorijskom periodu. Cilj rada je da prikaže uticaj dominantne politike na formiranje slike o društvu i istoriji, kroz analizu slučaja Spomenparka Kragujevački oktobar u Šumaricama u Kragujevcu. Nakon Drugog svetskog rata težilo se ka novoj formi spomen-parka. Iako su zahtevi bili jasno koncipirani, odluke vlasti nisu bile dosledno sprovođene što je dovelo do nepotpunog ispunjavanja planova u izgradnji parka. Uprkos tome, u okviru spomen-parka i memorijalnog muzeja ostvarena su umetnička dostignuća visokog dometa, najčešće kroz sintezu različitih umetničkih disciplina. Metodom ritamanalize biće opisan uticaj odluka o razvoju spomen-parka na ostvarivanje $\mathrm{i}$ izbor umetničke produkcije, kao i uticaj na promene u svakodnevnom životu lokalne zajednice.

KLJUČNE REČI: MEMORIJALNI SPOMENIK, MEMORIJALNI MUZEJ, SINTEZA UMETNOSTI, RITAMANALIZA, SPOMEN-PARK KRAGUJEVAČKI OKTOBAR

Akademski kurs:

KUSTOSIRANJE: Tehnologija izložbenog procesa /

Realizacija projekta - "stvaran svet"

\section{Andrej Bereta, Srdjan Tunić}

Kao produžena aktivnost nezavisnog kustoskog projekta Kustosiranje / About and around curating, istoričari umetnosti i freelance kustosi Bereta i Tunić su razvili poseban akademski kurs za Univerzitet u Beogradu - Arhitektonski fakultet i Fakultet likovnih umetnosti tokom jesenjeg semestra 2012/13. god. Zasnovan na metodologiji iskustvenog učenja i inspirisan savremenim kustoskim studijama u Evropi, kurs je imao zvaničan kurikulum koji je u sebe okupio studente osnovnih studija arhitekture, primenjenih umetnosti (Odeljenje za vajarstvo) i istorije umetnosti. Cilj kursa je bio da podstaknemo timski rad studenata sa različitih studija da bi zajednički napravili nova umetnička dela, kao deo grupne izložbe. Sam kurs je bio oblikovan kao reakcija i konstruktivna kritika nedostatku saradnje između umetničkih fakulteta, malog broja praktičnih aktivnosti tokom studija i sagledavanju kustoskih studija kao čistog sveta ideja. 